\title{
INISIASI ASI TERHADAP MOTORIK BAYI DI RW 08 DUSUN LEBAKJATI DESA CILELES KECAMATAN JATINANGOR
}

\author{
In-In Hanidah ${ }^{1}$, Indira Lanti' ${ }^{1}$, Wendry Setiyadi Putranto ${ }^{2}$, Fitri Hasnaulia Wargadipura ${ }^{3}$, \\ Erma Rismayanti ${ }^{4}$, Widiati Oktaviani ${ }^{5}$, dan Diemas Ridha Rizkiana ${ }^{6}$ \\ ${ }^{1}$ Dosen Teknologi Pangan, Universitas Padjadjaran \\ ${ }^{2}$ Dosen Teknologi Produksi Ternak, Universitas Padjadjaran \\ ${ }^{3}$ Mahasiswa Teknologi Pangan, Universitas Padjadjaran \\ ${ }^{4}$ Mahasiswa Fakultas Ilmu Budaya, Universitas Padjadjaran \\ ${ }^{5}$ Mahasiswa Fakultas Ilmu Komunikasi, Universitas Padjadjaran \\ ${ }^{6}$ Mahasiswa Fakultas Peternakan, Universitas Padjadjaran \\ E-mail: inin@unpad.ac.id
}

\begin{abstract}
ABSTRAK. ASI merupakan sumber nutrisi yang sempurna untuk bayi, karena mengandung nutrisi lengkap, beragam mikrobiota, dan berbagai komponen aktif biologis yang dapat meningkatkan sistem imun. Tidak sedikit Ibu menyusui mengetahui pengaruh inisiasi ASI terhadap perkembangan gerak motorik bayi, sehingga lebih memilih pemberian susu formula. Tujuan penelitian ini adalah untuk melihat kebiasaan inisiasi serta pengaruh ASI terhadap bayi. Penelitian dilaksanakan bulan September - November 2018 di Desa Cileles RW 08. Subjek penelitian ibu dan bayi usia 0-24 bulan. Teknik pengambilan sampel metode sensus komunitas masyarakat, pengumpulan data yang digunakan adalah observasi dengan mengamati gerak refleks motorik bayi, serta menggunakan teknik wawancara untuk menggali informasi melalui bertanya secara tatap muka. Teknik analisa yang digunakan adalah dengan mendeskripsikan data yang diperoleh di lapangan. Berdasarkan hasil analisis, diperoleh kesimpulan bahwa bayi yang mendapatkan ASI dari ibunya secara penuh dari usia 0-24 bulan menghasilkan gerak rekleks motorik level $4-5$ yaitu dapat melakukan aktivitas yang seimbang dengan perkembangan usianya.
\end{abstract}

Kata kunci: menyusui; ASI; bayi; refleks; motorik.

ABSTRACT. The purpose of this study was to see the initiation habits of breastfeeding and the effect of breast milk on infant. This research is a descriptive qualitative study with subjects of mothers and infant aged 0-24 months. The data collection technique used is observation by observing infant reflexes, and using interview techniques to gather information through asking face-to-face. The analysis technique used is to describe the data obtained in the field. Based on the results of the analysis, it was concluded that infant who get breast milk from their mothers in full from the age of 0-24 months produce good infant reflexes and can carry out activities that are balanced with the development of their age.

Key words: breastfeeding; breast milk; infant; refkexes; motoric.

\section{PENDAHULUAN}

Secara geografis, Desa Cileles merupakan salah satu Desa yang berada di Kecamatan Jatinangor Kabupaten Sumedang yang terdisi dari 4 (empat) Dusun, 37 Rukun Tetangga (RT), dan 10 Rukun Warga (RW) berbatasan dengan: Desa Cilayung Kecamatan Jatinangor di sebelah utara, Desa Hegarmanah Kecamatan Jatinangor di sebelah selatan, Desa Kuta Mandiri Kecamatan Tanjung Sari di sebelah Timur, dan Desa Cibesi Kecamatan Jatinangor di sebelah Barat. Luas wilayah Desa Cileles yaitu 320 Ha dengan bentuk permukaan tanah pegunungan yang memiliki rata-rata ketinggian 200-700 mdpl dan suhu rata-rata harian $23^{\circ} \mathrm{C}-28^{\circ} \mathrm{C}$ per tahun.

Penduduk Desa Cileles RW 08 umumnya bermata pencaharian sebagai petani dan sebagai pekerja K3L di Unpad dengan latar pendidikan tertinggi SMA dan sederajat. Keterbatasan pengetahun mengenai gizi dan sistem metabolisme di dalam tubuh, menyebabkan masyarakat tidak terlalu memperhatikan nutrisi makanan yang dikonsumsi baik pada saat hamil, menyusui, maupun menyediakan makanan untuk keluarga.

Keaktifan atau gerak motorik bayi pada usia 0-24 bulan merupakan hal dasar yang dapat menentukan pola pikir dan kecerdasannya. Untuk perkembangan pola pikir, seorang bayi harus memiliki sistem imun atau kekebalan tubuh yang baik serta terpenuhi kebutuhan nutrisinya. Nutrisi dan imun bagi bayi usia 0-24 bulan dapat terpenuhi dengan ASI (Air Susu Ibu). ASI merupakan makanan yang sempurna dan terbaik bagi bayi karena mengandung senyawa untuk pembentukan sistem imun yang merupakan komponen biokimia pembentuk sistem kekebalan tubuh dan ketahanan untuk melawan infeksi (Witkowska-zimny, 2017)

Perkembangan bayi sangat didukung dengan kondisi fisik dan kesehatannya. Sistem imun atau sistem kekebalan tuhuh bayi terhadap berbagai penyakit harus diperhatikan. Salah satu cara mempertahankan kekebalan tubuh bayi terhadap berbagai penyakit yaitu dengan cara mempertahankan jumlah probiotik yang ada dalam tubuh bayi (Kisty Le Doare, Beth Holder, Aisha Bassett, 2018). Salah satu sumber probiotik alami untuk bayi yaitu ASI (Boix-amorós et al., 2016). Terdapat dua sifat zat dalam kandungan ASI yaitu Nutrien dan Proktektif. Nutrien di dalam ASI meliputi: lemak, karbohidrat, protein, garam dan mineral, dan vitamin. Dan untuk zat yang bersifat protektif meliputi: lactobasillus bifidus, lactoferin, lisozim, komplemen $\mathrm{C} 3$ dan $\mathrm{C} 4$, faktor antistreptokokus, antibodi, 
imunitas seluler, dan tidak menimbulkan alergi (Ella et al., 2009).

Proses pemberian air susu kepada bayi atau yang disebut dengan Inisiasi ASI harus dilakukan sejak dini. Istilah yang dipakai disini yaitu Inisiasi Menyusui Dini (IMD). Inisiasi menyusui dini merupakan kondisi ketika bayi mulai menyusu sendiri setelah lahir, yaitu ketika bayi memiliki kemampuan untuk menyusu sendiri, dengan kriteria terjadi kontak kulit ibu dengan kulit bayi setidaknya dalam waktu 60 menit pertama setelah bayi lahir (UNICEF, 2006).

Bayi yang diberi ASI sesuai dengan waktunya yaitu dari usia 0-6 bulan akan memiliki sistem imun yang kuat serta nutrisinya terpenuhi. Sehingga gerak motoriknya akan tumbuh dengan baik. Kesadaran dan pengetahuan mengenai ASI sangat penting bagi wanita yang sudah dan akan mempunyai bayi. Agar menumbuhkan bayi-bayi yang cerdas dan sehat. Selain untuk menjaga kesehatan bayi, secara tidak langsung mereka juga menjaga kesehatan dirinya sendiri. Para Ibu harus menjaga bayi sejak dini.

ASI merupakan suatu cairan hidup yang dapat berubah dan memberi respon terhadap kebutuhan bayi seiring dengan pertumbuhannya (Welford, 2008). Terdapat dua sifat zat dalam kandungan ASI yaitu Nutrien dan Proktektif. Nutrien di dalam ASI meliputi: lemak, karbohidrat, protein, garam dan mineral, dan vitamin. Dan untuk zat yang bersifat protektif meliputi: lactobasillus bifidus, lactoferin, lisozim, komplemen C3 dan C4, faktor antistreptokokus, antibodi, imunitas seluler, dan tidak menimbulkan alergi.

Pemberian ASI dengan mendekap bayi dapat merangsang kecerdasan emosional. Doa dan harapan yang didengungkan selama proses menyusui dapat mengasah kecerdasan spiritual bayi. ASI Memiliki beberapa manfaat bagi ibu, antara lain: (1) Mencegah perdarahan pascapersalinan; (2) Mempercepat involusi uteri; (3) Mengurangi resiko anemia; (4) Mengurangi resiko kanker ovarium dan payudara; (5) Memperkuat ikatan ibu dan bayi; (6) Mempercepat kembali ke berat badan semula; dan (7) Metode kontrasepsi sementara. Pemberian ASI Eksklusif merupakan cara pemberian makanan yang sangat tepat dan kesempatan terbaik bagi kelangsungan hidup bayi di usia 6 bulan, dan melanjutkan pemberian ASI sampai umur 2 tahun (Harnowo, 2012)

\section{METODE}

Penelitian dilaksanakan di RW 08 Dusun Lebakjati Desa Cileles Kecamatan Jatinangor Kabupaten Sumedang. Subjek penelitian bayi usia 0-24 bulan (14 orang). Teknik pengambilan sampel metode sensus komunitas masyarakat RW 03 Desa Cileles. Pengumpulan data yang digunakan dengan cara observasi mengamati gerak refleks motorik bayi, serta menggunakan teknik wawancara untuk menggali informasi melalui bertanya secara tatap muka.
Teknik analisa yang digunakan adalah dengan mendeskripsikan data yang diperoleh di lapangan berdasarkan data hasil observasi kemudian dianalisis kembali dengan menggunakan deskriptif analitik untuk mendapatkan data yang faktual dan akurat. Selanjutnya data disusun dan dibuat penarikan kesimpulan.

\section{HASIL DAN PEMBAHASAN}

Inisiasi ASI yang baik dan benar sangat penting dilakukan untuk menunjang pertumbuhan dan perkembangan bayi balita hingga ia dewasa. Namun sangat disayangkan Inisiasi ASI di Desa Cileles kurang diperhatikan oleh ibu yang sedang menyusui. Pemberian ASI bagi balita di Desa Cileles belum memenuhi waktu yang telah dianjurkan yaitu usia 0-24 bulan.

Berdasarkan hasil wawancara kepada 14 ibu bayi usia 0 - 24 bulan di RW 08 Desa Cileles Kecamatan Jatinangor didapatkan informasi bahwa di daerah tersebut masih jarang adanya penyuluhan mengenai pentingnya ASI. Sebanyak 10 dari 14 ibu bayi usia $0-24$ bulan di RW 08 masih belum mengetahui adanya kandungan probiotik yang penting bagi bayi di dalam ASI. Ibu yang telah mengetahui mengenai adanya kandungan probiotik bagi bayi dalam ASI hanya 28,6\% dari total sensus. Informasi yang mereka peroleh dari buku bunda ketika hamil dan tayangan televisi.

Waktu pemberian ASI kepada balita di RW.08 cukup beragam, mulai dari rentang waktu yang paling sedikit yaitu bayi usia 21 hari sampai rentang waktu yang paling lama yaitu usia 22 bulan. Banyak ibu yang tidak bisa memenuhi kebutuhan ASI sampai usia 2 tahun bagi bayinya dengan berbagai alasan diantaranya karena tuntutan pekerjaan dan kondisi fisik ibu. Sehingga untuk memenuhi kebutuhan nutrisi dari ASI, diperlukan tambahan susu formula. Namun berdasarkan hasil wawancara $35,7 \%$ ibu yang masih memberikan ASI ekslusif bagi bayinya.

Usia dini merupakan suatu periode masa keemasan anak, karena pada usia ini anak akan mengalami tingkat perkembangan yang sangat drastis di mulai dari pekembangan berpikir, perkembangan emosi, perkembangan motorik, perkembangan fisik dan perkembangan sosial (Febrianta, 2017).

Hasil obeservasi di lapangan menunjukan bahwa sebagian besar gerak motorik yang ada pada bayi usia 0-24 bulan di RW .08 Desa Cileles Kecamatan Jatinangor yang berjumlah 14 orang rata-rata memiliki nilai refleks mototrik 4.75 (Gambar 1). Nilai 0 menunjukan tidak ada kontraksi sama sekali, nilai 1 menunjukan hanya ada kontraksi, nilai 2 menunjukan ada kemampuan gerak tapi tidak dapat melawan gravitasi bumi, nila 3 menunjukan ada kemampuan gerak untuk melawan gravitasi bumi, nilai 4 menunjukan ada gerakan tapi tidak penuh, dan nilai 5 menunjukan kekuatan penuh untuk melakukan akivitas. 


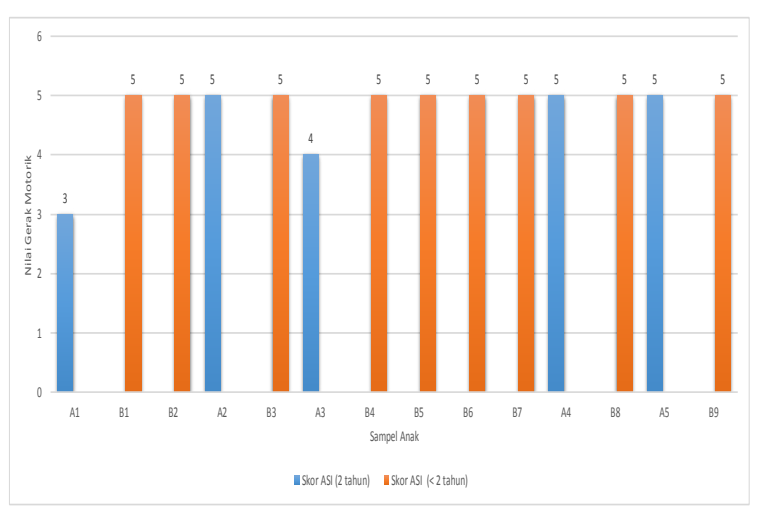

Gambar 1. Nilai Gerak Refleks Motorik Bayi Usia-24 bulan

Rata - rata skor gerak motorik bayi usia 0-24 bulan di RW 08 Desa Cileles dengan waktu pemberian ASI < 2 tahun yaitu mencapai angka 5, dimana data tersebut menggambarkan bahwa bayi-bayinya dapat melakukan kekuatan penuh dalam beraktivitas. Sedangkan rata - rata skor gerak motorik bayi usia 0-24 bulan di RW 08 Desa Cileles dengan waktu pemberian ASI 2 tahun yaitu 4,4 dapat digambarkan bahwa skor tersebut menunjukan bayi mampu melakukan gerakan tapi tidak penuh.

Hasil analisis data menunjukan bahwa bayi balita yang diberi ASI sampai 2 tahun memiliki skor gerak motorik lebih kecil dibandingkan dengan skor gerak motorik bayi balita yang diberi ASI kurang dari 2 tahun yang memiliki skor 5. Hal ini disebabkan karena bayi balita yang mendapatkan ASI kurang dari 2 tahun juga mendapatkan asupan nutrisi tambahan susu formula yang dapat berpengaruh terhadap gerak motorik bayi pada saat itu, dimana perkembangannya sangat cepat karena kandungan nutrisinya sangat kuat. Akan tetapi, adanya kekurangan dalam susu formula yakni dalam susu formula tidak mengandung bakteri baik untuk menjaga kesehatan saluran cerna atau probiotik yang dapat meningkatkan kekebalan tubuh. Sedangkan bayi balita yang diberi ASI menuju 2 tahun perkembangannya sesuai dengan proses pemberian ASI, dimana kandungan ASI yang masuk ke dalam tubuh bayi tanpa susu formula akan bekerja secara bertahap namun bisa menunjang sistem imun dan nutrisi pada bayi dengan optimal hingga dewasa.

Menurut (Septiana, dkk., 2010), salah satu penyebab terjadinya gangguan tumbuh kembang bayi dan anak usia 6 sampai 24 bulan di Indonesia adalah rendahnya mutu MP-ASI (makanan pendamping ASI) dan ketidak sesuaian pola asuh yang diberikan sehingga beberapa zat gizi tidak dapat mencukupi kebutuhan energi dan zat mikro terutama zat besi ( $\mathrm{Fe})$ dan Seng ( $\mathrm{Zn})$. Pemberian makanan adalah salah satu faktor yang mempengaruhi status gizi bayi. Pemberian makanan yang kurang tepat dapat menyebabkan terjadinya kekurangan gizi dan pemberian yang berlebihan akan terjadi kegemukan. Pada usia 6 bulan, secara fisiologis bayi telah siap menerima makanan tambahan, karena secara keseluruhan fungsi saluran cerna sudah berkembang. Selain itu, pada usia tersebut air susu ibu sudah tidak lagi mencukupi kebutuhan bayi untuk tumbuh kembangnya, sehingga pemberian MP-ASI sangat diperlukan.

PemberianASIEksklusifmerupakan cara pemberian makanan yang sangat tepat dan kesempatan terbaik bagi kelangsungan hidup bayi di usia 6 bulan, dan melanjutkan pemberian ASI sampai umur 2 tahun (Harnowo, 2012). Uji lanjut untuk mengetahui perkembangan sistem gerak motorik bayi usia 0-24 bulan di Desa Cileles, dilakukan dengan menggunakan klasifikasi sistem yang dibuat oleh Robert Palisano (Tabel 1). Gerak motorik dibagi menjadi dua, yaitu motorik halus dan motorik kasar. Gerak motorik halus merupakan gerakan yang menggunakan otot-otot halus, seperti: memindahkan benda dari tangan, mencoretcoret, dan menyusun balok. Motorik kasar merupakan gerakan tubuh yang menggunakan otot-otot besar, seperti menendang, berlari, dan naik turun tangga. Koordinasi gerak motorik diatur oleh otak kecil (cerebellum).

Tebel 1. Klasisfikasi Perkembangan Gerak Motorik Bayi Usia 0-24 bulan

\begin{tabular}{|c|c|c|c|}
\hline $\begin{array}{l}\text { Sampel } \\
\text { Bayi }\end{array}$ & $\begin{array}{c}\text { Usia Bayi } \\
\text { (bulan) }\end{array}$ & Nilai & Deskripsi \\
\hline A1 & 2 & 4 & $\begin{array}{l}\text { Bisa menggerakan kepala dan } \\
\text { telentang }\end{array}$ \\
\hline B1 & 2 & 4 & $\begin{array}{l}\text { Telentang, hanya tangan dan } \\
\text { kepala yang bisa digerakan }\end{array}$ \\
\hline B2 & 13 & 2 & $\begin{array}{l}\text { Sudah bisa jalan, namun harus } \\
\text { bisa dibantu, serta sudah bisa } \\
\text { duduk. }\end{array}$ \\
\hline A2 & 12 & 2 & $\begin{array}{l}\text { Sudah bisa merangkak, jalan } \\
\text { masih dibantu, dan sudah bisa } \\
\text { memegang mainan. }\end{array}$ \\
\hline B3 & 12 & 2 & $\begin{array}{l}\text { Sudah bisa jalan tetapi masih } \\
\text { dibantu, sudah bisa tertawa. }\end{array}$ \\
\hline A3 & 12 & 3 & Baru bisa duduk dan merangkak. \\
\hline B4 & 23 & 1 & $\begin{array}{l}\text { Sudah bisa jalan, bermain, dan } \\
\text { berbicara. }\end{array}$ \\
\hline B5 & 22 & 1 & $\begin{array}{l}\text { Sudah bisa berjalan, berbicara, } \\
\text { tertawa, dan bermain. }\end{array}$ \\
\hline B6 & 22 & 1 & $\begin{array}{l}\text { Sudah bisa berjalan, berbicara, dan } \\
\text { bermain. }\end{array}$ \\
\hline B7 & 22 & 1 & $\begin{array}{l}\text { Sudah bisa berjalan, bermain, dan } \\
\text { berbicara. }\end{array}$ \\
\hline A4 & 18 & 1 & $\begin{array}{l}\text { Sudah bisa berjalan, berbicara } \\
\text { namun masih takut pada orang } \\
\text { yang baru ia kenal. }\end{array}$ \\
\hline B8 & 14 & 2 & $\begin{array}{l}\text { Jalan masih dibantu, bicara masih } \\
\text { terbata-bata, dan sudah bisa } \\
\text { merangkak. }\end{array}$ \\
\hline A5 & 1 & 5 & $\begin{array}{l}\text { Gerakannya masih terbatas hanya } \\
\text { kepala, bibir (mencari ASI), dan } \\
\text { tangan. }\end{array}$ \\
\hline B9 & 15 & 1 & Sudah bisa berjalan, bermain. \\
\hline
\end{tabular}

Berdasarkan klasifikasi sistem yang dibuat oleh Palisano et al. (2007) perkembangan gerak motorik anak terdiri dari beberapa tahap, antara lain:

1) Tingkat I: Bayi masuk dan keluar duduk dan duduk di lantai dengan kedua tangan bebas untuk memanipulasi objek. Bayi merangkak ditangan dan lutut, tarik untuk berdiri dan mengambil langkah-langkah memegang furnitur. Bayi berjalan antara 18 bulan dan 2 tahun tanpa perlu setiap perangkat mobilitas bantu. 
2) TingkatII:Bayitetapdudukdilantaitetapimungkinperlu menggunakan tangan mereka untuk mendukung untuk menjaga keseimbangan. Bayi merayap pada mereka perut atau merangkak di tangan dan lutut. Bayi dapat menarik untuk berdiri dan mengambil langkah-langkah memegang furnitur.

3) Tingkat III: Bayi mempertahankan lantai saat punggung bagian bawah didukung. Bayi menggulung dan merayap maju di perut mereka.

4) Tingkat IV: Bayi memiliki kontrol kepala tetapi dukungan batang diperlukan untuk duduk di lantai. Bayi dapat berguling hingga terlentang dan mungkin berguling-guling.

5) Tingkat V: Kerusakan fisik membatasi kontrol gerakan secara sukarela. Bayi tidak dapat mempertahankan kepala dan batang anti-gravitasi postur di rawan dan duduk. Bayi membutuhkan bantuan orang dewasa untuk berguling.

Secara keseluruhan, tahap perkembangan gerak motorik bayi usia 0-24 bulan di Desa Cileles sudah cukup baik. Hal ini dikarenakan selain dipengaruhi asupan nutrisi dari ASI juga dipengaruhi oleh MP-ASI yang mengnadung nutrisi cukup baik.

\section{SIMPULAN}

Inisiasi ASI merupakan pemenuhuan kebutuhan lengkap nutrisi bayi 0-6 bulan, kualitas MP ASI, rangsangan dan stimulus secara teratur akan memberikan hasil optimal terhadap perkembangan gerak motorik bayi. Tahap perkembangan gerak motorik bayi dilihat berdasarkan standar Robert Paliseno, dapat dideskripsikan bahwa sebagian besar gerak motorik bayi usia 0-24 bulan di RW. 08 Desa Cileles cukup baik.

\section{UCAPAN TERIMAKASIH}

Ucapan terimakasih kami sampaikan kepada Rektor Universitas Padjadjaran atas bantuan dana KKN dan PKM melalui dana Hibah HIU; serta seluruh masyarakat RW 08 Desa Cileles Kecamatan Jatinangor atas kerjasama untuk mengambilan data.

\section{DAFTAR PUSTAKA}

Boix-amorós, A., Collado, M. C., \& Mira, A. (2016). Relationship between Milk Microbiota , Bacterial Load, Macronutrients, and Human Cells during Lactation. Frontiers in Microbiology, 7(April), 1-9. https://doi.org/10.3389/fmicb.2016.00492
Ella, E. E., Ahmad, A. A., Umoh, V. J., Ogala, W. N., \& B, B. T. (2009). Lactoferrin levels in human breast milk among lactating mothers with sick and healthy babies in Kaduna State, Nigeria. International Journal of Medicine and Medical www.academicjournals.org/journal/IJMMS/ article-abstract/960C7BE387

Febrianta, Y. (2017). Model Pembelajaran Motorik Yang Menyenangkan. Jurnal Pendidikan Ke-SD-An, 3, 184-188.

Harnowo dalam Rahmawati. (2012). Hubungan Faktor Budaya. Fakultas Ilmu Kesehatan UMP.

Kisty Le Doare, Beth Holder, Aisha Bassett, and P. S. P. (2018). Mother's Milk : A Purposeful Contribution to the Development of the infant Microbiota and immunity. Frontiers in Immunology, 9(February), 1-10. https://doi.org/10.3389/fimmu.2018.00361

Palisano, R. R., Rosenbaum, P., Bartlett, D., \& Livingston, M. L. (2007). Gross Motor Function Classification System Expanded and Revised. CanChild Centre for Childhood Disability Research, Institute for Applied Health Sciences, McMaster University, $1-4$.

Rika Septiana, R Sitti Nur Djannah., M. D. D. (2010). HUBUNGAN ANTARA POLA PEMBERIAN MAKANAN PENDAMPING ASI ( MP-ASI ) DANSTATUSGIZIBALITAUSIA6-24BULAN. KES MAS, 4(2), 118-124. Retrieved from https:// media.neliti.com/media/publications/24835ID-hubungan-antara-pola-pemberian-makananpendamping-asi-mp-asi-dan-status-gizi-bal.pdf

UNICEF. (2006). Melindungi, Meningkatkan, dan Mendukung Menyusui: Peran Khusus pada Pelayanan Kesehatan Ibu Hamil dan Menyusui. (C. dan R. Suradi, Ed.). Jakarta: Perkumpulan Perinatologi Indonesia.

Welford, H. (2008). Menyusui Bayi Anda. Jakarta: Dian Rakyat.

Witkowska-zimny, M. and E. K. E.-H. (2017). Cells of human breast milk. Cellular \& Molecular Biology Letters, 1-11. https://doi.org/10.1186/s11658-0170042-4 